Fifteenth Scientific Meeting-Se-Sentin Scotrish Meeting

Royal INFIRMary, EDINBURGh, OCTOBER 2ND, 1943

\title{
THE HOT SPRINGS CONFERENCE
}

\author{
Chairman, Professor D. Murray Lyon \\ The United Nations Conference on Food and \\ Agriculture, Hot Springs, Virginia, \\ 18th May-3rd June, 1943
}

Dr. K. Evang (Royal Norwegian Ministry of Social Welfare, Kingston House, Prince's Gate, London, S.W.7)

I will try to give you a picture of the Conference itself and also an account of some of the resolutions and recommendations adopted and their importance from the nutritional point of view. I was deeply impressed with the unity of the Conference. On this occasion there met, for the first time during the war, representatives of all the United Nations, 44 in number, and, in addition, an observer from Denmark, these representing about 75 per cent. of the total population of the world. There were 161 delegates and a great number of experts. The Conference has been called the first part of the United Nations' peace conference, but unlike other peace conferences its representatives were not only diplomats, politicians and generals but experts in nutrition, economics and agriculture who were there not merely as advisers but as responsible members of the delegation.

No less than 10 of the countries represented were at the time totally occupied by the enemy, two were partly occupied and one was occupied by the Allied forces.

The Conference went down to the very bottom, to the things which had created the circumstances of strain which finally led to war, economic problems, the difference in the standard of living in different countries, the difference of class in each country. It really dealt with the problems which the people themselves felt should be dealt with. We all knew that all people were consumers of foodstuffs, but not all of us knew that twothirds of the world's population were producers of foodstuffs. The tremendous task of the Conference was to reach agreement between the 44 nations, during the war itself, on certain plans for the production, distribution, transport and consumption of food all over the world after the war.

Why was the Conference called just at that time? The feeling amongst the delegates was that the Allied leaders, and especially Mr. Roosevelt, had felt that, although the United Nations had been fighting together very well for a long time, yet they did not feel themselves to be a working organization or team, and it would be a good thing if they could get together on some positive work. Agreement could be hoped for during the war which might not be so easily attained after the war was over.

vos, 2, 1944]

163 
A great deal of confusion has been created because at the same time that the Hot Springs Conference was in being the UNRRA conference was being prepared, to meet in November 1943 in the U.S.A. It was to deal with different problems.

The Conference recommended that immediate steps should be taken in all countries to produce as much as possible of the foodstuffs most needed and also to provide for the transportation of food. The United Nations were resolved to do everything in their power to relieve the hunger of those heroic peoples whose liberation is now approaching.

In between the period provided for by UNRRA and that provided for by the Hot Springs Conference there will be a transitional period in which the world food production and transportation will be settling down from war conditions to normal, and the British delegation was very anxious to have the Conference express some views on this.

The Conference worked in 4 sections. Section 1 dealt with consumption levels and requirements. Section 2 dealt with agricultural aspects, measures for increasing production of commodities for which the demand has increased, and for cutting down production of commodities which are in chronic surplus. Section 3 dealt with the economic part of the problem. Section 4 dealt with recommendations for the carrying forward of the work of the Conference.

It has been said by many of the members that the U.S.A. was not the place for such a Conference; the Americans were without experience in international work. That view proved utterly wrong. From the administrative point of view the Conference was very good; the preparations and organization were excellent and everything worked very smoothly. It was also a good idea to bring all the delegates together in a communal hotel. The opportunities of meeting the delegates from other countries in between the regular mectings were useful in the solving of many problems. I have been at other international conferences, and at Hot Springs I was interested to see how people had changed. There was an absence of academic hair splitting discussion and no one got up to speak unless he had something to say. The one cloud was the initial antagonism of the American press, the result of a difference between the newspaper men and the American Administration, but this situation improved greatly before the end of the Conference.

The attitude of the delegates was, at first, sceptical. They were people who had lived through one world war, had seen the rise of the League of Nations, had seen the failure of the League and were now in the midst of a second world war. They questioned why the Conference had been called. Everything had probably been decided beforehand and they had only been called together to look over it. But the first 2 or 3 days of the Conference were used to discuss and prepare the agenda, so that the delegates felt that they themselves had a say in what was going to be done. After the first 2 or 3 days there was a feeling of strong optimism and after a week a spirit of enthusiasm.

The outstanding feature of the Conference, in my opinion, was the fact that two leading world powers, who had previously been reluctant to join in any responsibility for international co-operation, both voted without any reserve for international co-operation in this very important field after the war, namely the U.S.A. and Soviet Russia. 
Another outstanding feature was that the Hot Springs Conference stated, in more clear and courageous words than ever before, some fundamental truths about the food problems of the day. The declaration of the Conference stated that: "There has never been enough food for the health of all people. This is justified neither by ignorance nor by the harshness of nature. Production of food must be greatly expanded; . . .

"The first cause of hunger and malnutrition is poverty. It is useless to produce more food unless men and nations provide the markets to absorb it." (United Nations Conference on Food and Agriculture, 1943, 1.)

A great point was that the Conference did not confine itself to generalities. It recommended special measures and struck a note of urgency, asking for immediate action.

It is only fair to remember that international work on nutrition is not an uncharted field at all and the Hot Springs Conference could not possibly have reached the results it did without having a good broad basis upon which to build in the work already done by the League of Nations. It carried that work a few steps farther. In that connexion I wish to pay tribute to Sir John Boyd Orr, whose work, more than that of any other single individual, made the Hot Springs Conference possible.

The work of the League of Nations was limited. Its workers were brought together mostly from the countries within the area of Western civilization. Now other parts of the world are brought into the picture, South America, China, the East Indies, the Middle East and even the Colonial Dependencies.

Another feature of the Conference was that some of the belligerent countries represented, the United Kingdom for example, had been forced during the war to adopt a food policy and had had great success with it. Section 1 of the Report made a special point of that.

The reports from other parts of the world made a very deep impression on the Conference. So far as the countries of western Europe were concerned, between one-third and one-quarter of the population was undernourished, even in peace time, but the picture from India showed that out of a population of nearly 400 millions the large majority did not even get enough to eat.

What was the answer of the Conference to this situation? The answer was: expanded production of foodstuffs, internationally planned and coordinated transportation and distribution of food all over the world. The government of each country would be responsible for seeing that each individual in the country received an adequate diet. They would also be responsible for taking active steps, through medical and public health officers and others, to make secure the more vulnerable groups, pregnant and nursing women, babies, children and young people, to educate the population and to regulate prices.

In my opinion, a very important point was that the Conference all the time stressed the fact that it was the duty of the governments and responsible authorities of the different countries to express to their own people that they had this responsibility and that it was their further duty to report regularly to one another, through national and international bodies created for that purpose, on the progress of the work. In other words the Hot Springs Conference created a sort of world conscience in regard to the food supply of the world.

voL. 2, 1944] 
I recommend everyone to read the Reports of the Conference, two publications of H.M. Stationery Office: The Final Act and The Sectional Reports (United Nations Conference on Food and Agriculture, 1943, 1, 2). Through its recommendations as to the relationship between food and health the Hot Springs Conference has demonstrated its modern point of view. There are the specific deficiency diseases, beriberi, scurvy, pellagra. There is the even more important problem of the disease which is influenced by the food of individuals, tuberculosis for example. Most important of all perhaps is the fact that an individual who has been living for a long time on a good, balanced diet will have greater powers of resistance against almost every ailment than an individual who has been malnourished.

With reference to the short term policy, on which the British delegation was specially anxious to have the views of the Conference expressed, that is, policy during the transition period at the end of the war, I shall quote passages from Judge Marvin Jones's summing up. There will be a general shortage of foodstuffs. Until the production of the staple food crops in the devastated areas is restored, it will be necessary, first, to ensure production of energy foods and we shall not be concentrating upon the protective foods. Later the emphasis will shift to protective foods.

Section 2 of the Report contains some striking points about bringing new parts of the world under cultivation. Sometimes there is overcrowding of farms, and the development of intensive farming and emigration are the only remedies. Freedom from want cannot be achieved unless there is belief in world wide expansion.

Section 3 deals with distribution. Sometimes it will not be possible for the decisions to be applied unless the workers meet together through international action to raise the standard of employment. Poverty is the first cause of malnutrition and hunger.

In conclusion I should like to try to describe the fine spirit of the Conference itself. There was a feeling of great trust and faith in the future, and, in my opinion, the reason for this was the experience of international democracy at the Conference. There was still a tendency for the words spoken by the representatives of the great powers to carry more weight than those of the smaller ones, but it was appreciated that in some cases a smaller country had been able to solve a problem which was still unsolved by a great country. At Hot Springs, from the first, there was created a feeling that it was the quality of what was said more than the man who said it or the country from which he came that mattered. It will be the task of the Allied Nations to build upon the foundation laid at Hot Springs. Nothing will happen without action on their part, but, if the United Nations continue their co-operation in peace, the foundation has been laid for wellbeing and health, as well as peace and security. The Hot Springs Conference will then go down to history as a door of hope for mankind.

\section{References}

United Nations Conference on Food and Agriculture (1943, 1). Final Act of the United Nations Conference on Food and Agriculture. [Cmd. 6451]. London: H.M.S.O.

United Nations Conference on Food and Agriculture $(1943,2)$. Section Reports of the Conference. [Cmd. 6461]. London: H.M.S.O. 


\title{
The United Nations Interim Commission for Food and Agriculture
}

\author{
Mr. F. L. McDougall (Australia House, Strand, London, W.C.2)
}

I will try to give an account of the way in which the Interim Commission, which has been set up as a result of the recommendations of the Hot Springs Conference, is visualizing its work.

First I will make two comments on the Conference. (1) Comparison of the report of the Hot Springs Conference with that of the Mixed Committee on Nutrition made to the League Assembly (League of Nations, 1937) shows that the nations are bolder and prepared for more far reaching and constructive suggestions in 1943 than they were in 1937. (2) The new technique of the Conference was extraordinarily interesting. The governments appointed as delegates technical and expert people who really did know something about the subject they were discussing, and they gave these delegates authority to discuss in the fullest possible way the subject of food and agriculture, though without committing the governments. The Conference was segregated from the public for the 18 days of meeting, and it was found that there was complete agreement about objectives and very little disagreement about the methods of reaching objectives. The Conference adopted a series of resolutions and recommended that the governments should appoint an Interim Commission to carry these out and discuss them with the governments. This was a new technique likely to prove extremely useful if applied to international health, education and employment. The governments were asked to accept obligations to their own people and to one another and to report on the national action taken by each government, through this new permanent organization. The technique is not entirely new, because it was used with surprising success in one field of the League of Nations work, in between the two war periods, in the control of the trade and use of dangerous drugs, and this has resulted in the creation of a world conscience as far as dangerous drugs are concerned. The application of this idea to so wide a field as food and agriculture is something quite new.

The Interim Commission consists of one representative of each of the 44 United Nations. It was established on 15th July of this year and met in Washington. The members are mainly drawn from the Diplomatic Corps in Washington. The Interim Commission has three main tasks.

(1) To prepare the declaration whereby each government accepts as an obligation to its own people and to all other governments the duty of improving nutrition and agriculture and undertakes to report its progress. It is most fortunate and encouraging that before this could be prepared His Majesty's Government made a unilateral declaration accepting the whole of the Hot Springs Conference recommendations as far as applied to the United Kingdom.

(2) To prepare for governments the specific plans for the permanent organization on food and agriculture recommended by the Hot Springs Conference.

(3) To carry out any necessary interim aotivity pending the creation of the new permanent organization.

voL. 2, 1944] 
In order to discharge these tasks the Interim Commission organized itself into an executive and 3 working committees. Committee A has already prepared the declaration for the governments and this will shortly be submitted to all the governments of the United Nations. Committee B has two divisions, a technical advisory panel on the economic side and another on the scientific side, and these started work on 15th September. It has been suggested that they should regard themselves as having a time limit and should produce their reports on the principal functions of the new permanent body about the end of October or early November. Meanwhile the Secretariat, which is international in character, is studying the experiences of other international bodies and the constitutional issues. Some of the delegates thought that, instead of two technical advisory panels there should have been three, one on the nutritional aspect, one on the science of food and agriculture, and one on the general economic aspect. However, the scientific advisory panel will deal with the work of the permanent organization in relation to nutrition as well as to agricultural science. In addition to the Committees just described, there is also Committee $\mathrm{C}$, which is charged with the duty of considering what, if any, interim activity the Interim Commission should undertake. The Hot Springs Conference passed some very important resolutions on the subject of food and agriculture in the short term period which will immediately follow the cessation of hostilities, the period between what might be called the relief period, and the period when the recommendations of the Conference can be generally applied. They came to the conclusion that it was not the duty of the Interim Commission to undertake, or suggest to governments that they undertake, any activity in regard to relief supplies, but, as the Conference delegates were the representatives of the governments of all the United Nations, it was their clear duty to find out just what was being done by other bodies to bring about, first, a greater economy in the consumption of food in some countries, and then an increase in the production of the foods that would be most urgently needed if the wolf of hunger was to be kept at bay in the liberated countries, especially in Europe. Therefore the Commission is at present making a survey of what other organizations are doing. When the relief administration is established it will be its duty to deal with these problems but the Conference was anxious to see that there should not be any overlapping or initial delay between the production and distribution of food for war purposes and for dealing with relief problems.

The permanent organization which is to be set up will in many ways be new. There exists at the moment an International Institute of Agriculture with headquarters in Rome, which was established about 1905. It has an extremely wide charter as far as agriculture is concerned, but no duties in regard to food or any special interest in the consumer. This Institute has done effective work only in one line, viz., agricultural statistics. The Interim Commission has to prepare plans for a new permanent organization representative, to begin with, of all the United Nations, and later of all nations, to be an international authority for the whole world as far as food and agriculture are concerned. It is impossible as yet to give any idea of the scale of this organization but in all probability it will be a body at least twice the size of the International Labour Office, and, as far as its staff expenditure is concerned, will compare fairly closely 
with the League of Nations. This body will have to assume the functions of the Rome Institute but it will also have to discharge other important duties. It will have to interchange information between all countries, and will have to make statistical surveys of all countries, but probably more important than all these, it will have to put itself in a position to assist all those countries which lack organization for dealing with nutrition and agriculture so to organize that they will be able to attempt to move in the direction of carrying out the major recommendation of Hot Springs. In this connexion the countries of the world can be classified in three major groups:

(1) Those of western civilization which are already organized and will not need direct assistance.

(2) Those countries lacking organization in which population already presses severely on the present means of subsistence, e.g., India, China and many others. Even with the greatest possible efforts in the agricultural field, it will not be possible to bring about very great changes unless, simultaneously, it is possible to bring about a great increase in industrialization.

(3) The rest of the world in which also organization is lacking. In the Latin Americas, the Middle East and Africa, for example, there is no pressure of population on the soil. In these countries the application of the Hot Springs resolutions could bring about, in a very few years, quite astonjshing improvement in the standard of living.

It is to these countries in particular that the new permanent organization will have to direct a great deal of its attention. For countries like the United Kingdom and Australia, it will be of great importance in organizing conferences, supplying information and statistics and might be a rallying point for the "pressure groups" within our own countries who are anxious to see their own government driving a little more rapidly ahead.

This permanent organization will be only one of a series of linked international agencies, for international health, international investment, international development and so on.

After the Hot Springs Conference Dr. Thomas Parran, Surgeon-General to the U.S.A., got together an informal group of people who had been at Hot Springs and were greatly interested in the nutritional aspect. This group met 5 or 6 times and made informal suggestions for the consideration of the Interim Commission as to what ought to be done for nutrition. One point specially stressed was that, while there would be this new organization for food and agriculture, there must also be an international organization for health. There must be no overlapping or struggle between these two bodies if they are to work effectively together. My own view is that the permanent organization for food and agriculture will have to deal with nutrition if there is to be a rational plan for agriculture. I think it might be a mistake for the nutrition division of the permanent organization for food and agriculture to concern itself too much with the therapeutic aspects of the use of, say, vitamins. The therapeutic side of nutrition might perhaps be a particular aspect with which the health organization would deal, while the broader aspects were dealt with by the food and agriculture organization.

voc. 2,1944$]$ 
The nutrition division will have to be ready to participate with other divisions of the permanent organization in sending teams to help the less advanced countries in dealing with their problems. It will be necessary for it not only to have its own staff but also to make contacts with universities and research institutes, and it might set up a panel of persons who could be drawn upon by the permanent organization to obtain the necessary experience and knowledge for the teams they would be sending to help the various countries to face their problems. The nutrition division should itself undertake wide studies on the relation of food balance to national health, on maternity, infant and child welfare, deficiency diseases, and mortality and morbidity rates in the different countries.

Another important question is that of providing help to develop a suitable reporting technique. Many countries will have great difficulty in dealing with their reports so that the nutrition division ought to be very active in assisting the less advanced countries in methods of reporting.

One of the recommendations of Hot Springs was that every country should set up a national nutrition organization which would be given considerable powers. The nutrition division of the permanent organization will obviously have to be linked to the national health committees, and the less advanced countries will have to be assisted in the actual establishment of these committees.

Within the nutrition division of the permanent organization there ought to be 6 sub-committees, to deal with $(a)$ nutrition and health, (b) food consumption levels and food composition, (c) advisory work in co-operation with national nutrition committees, $(d)$ standards for food and food preparation, $(e)$ education and training, and $(f)$ animal nutrition and the study of the link between the nutrition and agricultural sections of the permanent organization.

The nutrition division of the permanent organization ought to have a branch office in Europe, one in each of the two Americas, one for the Far East and another for the Middle East.

In conclusion it seems to me of the utmost importance for the permanent organization and its nutrition division to get the goodwill and. active interest of the universities, research institutes, medical schools and all the bodies which might act as training centres and from which personnel might be drawn, either for the staffing of the permanent organization or to make up the teams which are to be sent out for one, two or three years to assist the backward countries in solving their food and agriculture problems.

I am quite certain that this organization will have to proceed slowly so far as the building up of its own permanent staff is concerned since everything will depend in the long run on the quality of the staff. On the other hand the problems the organization will have to tackle will be extremely urgent. Even now we ought to start sending delegations to the universities and other centres to enlist their active interest and co-operation in regard to the work that was done at the Hot Springs Conference and all the problems that have to be tackled in all the countries of the world. We could say to the academic and training college authorities: "Here is work of the most tremendous interest. Here is a task for which this new permanent organization simply must have the 
active, vigorous co-operation of the great universities, medical schools, agricultural and domestic science colleges of the more advanced countries of the world".

REFERENCES

League of Nations (1937). Final Report of the Mixed Committee of the League of Nations on the Relation of Nutrition to Health, Agriculture and Economic Policy, L.o.N. A. 13. 1937. II. A. Geneva.

United Nations Conference on Food and Agriculture (1943, 1). Final Act of the United Nations Conference on Food and Agriculture. [Cmd. 6451]. London: H.M.S.O.

United Nations Conference on Food and Agriculture $(1943,2)$. Section Reports of the Conference. [Cmd. 6461]. London: H.M.S.O.

\section{Discussion}

Sir John Orr (Rowett Research Institute, Bucksburn, Aberdeen): The Hot Springs Conference was an epoch making conference in view of the decisions which were taken. It recommended that every government should undertake to improve the nutrition of its people and continue to improve it until it came up to the health standard. It also recommended that, in addition to doing that within its own borders, each government should co-operate to get this done for all men in all lands. At present 75 per cent. of the world's population suffers either from hunger or from malnutrition, a big proportion from sheer hunger. If their food was brought up to standard, many years of life would be added to the population.

Another point is that 70 per cent. of the world's population are food producers, and some of them are sunk in abysmal poverty. If the Hot Springs policy was carried through, there would be a world market and fair prices for all these food producers, a great future for more than half the world population.

There is something even more important. At present, during the war, promises are being made to the common man, promises of a fuller life and the four freedoms. Promises like that were made during the last war, and if these promises are not fulfilled we shall go through the same cycle and have another war in another 25 years. On the other hand, if the nations accept the recommendations of the Hot Springs Conference and set themselves to carry them out, we shall go on in an ascending spiral of prosperity, and the expansion of world industry, trade and agriculture will then be deemed to be sound, not because of creating big fortunes, but because of promoting human welfare. There will be a different atmosphere after the war. We shall start to build a new and better world from the bottom upwards, beginning with the primary necessities of life for all.

After the last war the nations settled down to discuss political potentialities. If this time we can get the nations to sit down and discuss something constructive, if they will attempt to carry out the recommendations of the Conference, then something fundamental will begin to be achieved. If every nation, including our own, will proceed with this, we shall have the nations co-operating with each other for their mutual benefit, and, in working out a great world food plan, they might evolve a technique of international co-operation in investigating the conditions which produce the shortages.

vol. 2, 1944] 
Some people question whether the recommendations will be carried out. The British Government has already accepted them and is bound to carry them out, but they will not be carried out fully unless there is well informed and strong public opinion in favour of them; certainly not if the Government finds the people adopting a defeatist attitude, backed up by those who do not want the measures carried out. The important thing at present is to get this well informed public opinion and for each of those present to have faith to say "We know this will be done".

I hope that the wonderful speech of Dr. Evang will move everyone present to enthusiastic and burning belief that the recommendations are going to be carried out and that the carrying out of them will mark the beginning of the new era which will arise after this war.

Dr. M. Mead (American Museum of Natural History, New York): I am exceedingly interested in the sub-committees described by Mr. McDougall. It is particularly striking that they do not contain anywhere any recognition that, in addition to the problem of producing and distributing the food, and the problem of the nutritionist in studying what is necessary for the human organism, there is a third problem. The peoples of the world are organized in different ways and the food pattern and food organization are different in different countries. We know enough about the food habits of different groups to know that very often one could have malnutrition, not from any food shortage but because of the pattern of consumption, the use of white bread, for example, or polished rice. I feel certain the permanent organization would operate with maximum efficiency if it included in its province some of that sort of understanding so that, in each area of the world where the problem of food consumption is being considered, there would be careful consideration of the whole determining food pattern of the particular civilization concerned, and so one could operate with the maximum speed and the minimum dislocation of the different food patterns.

Dr. I. Leitch (Imperial Bureau of Animal Nutrition, Bucksburn, Aberdeen): I should like to ask Mr. McDougall how far the discussions at Hot Springs took account of magico-religious beliefs. The magicoreligious bogey is continually being raised in this country. It is even suggested that these beliefs affect the food consumption in Europe, a suggestion which I consider completely absurd. In countries in which these beliefs do appear to be extremely important, as in India, the real problem of nutrition seems to me to be, at least in part, the problem of the cattle. At present 10 cows are being used to produce what one cow ought to produce. If something could be done to correct this, a great many men could be fed on the acreage required to provide the starvation ration of the present unnecessary cows. Probably some of the other religious difficulties might be of simpler type.

In regard to world production, it is sometimes suggested that the problem is beyond the possibility of solution. When people tell me that the new world plan will require double the normal food output of the world, I find that very difficult to accept. Has the Hot Springs Conference reached any conclusion as to the total increase required in the energy foodstuffs, apart from the protective foodstuffs?

Can Mr. McDougall forecast a date when the permanent organization is likely to be born or to become active? 
Miss M. Andross (College of Domestic Science, Park Drive, Glasgow): With regard to the teams of workers mentioned by Mr. McDougall as part of the organization of the permanent commission, I think there would be special difficulty in the choice of personnel because of the fact that nutritionists, on the domestic and on the medical side, are in abysmal ignorance of economics and of agriculture. I think that if a delegation were to go round the universities, it should stress the desirability of a link being made by introducing a course of economics and of agriculture into the medical course.

Would Mr. McDougall consider introducing into his list of experts required for the teams, the people who prepare food, i.e., the domestic science workers, as well as the agricultural experts?

Dr. E. C. Owen (Hannah Dairy Research Institute, Kirkhill, Ayr): I think Dr. Evang quoted Dr. Sebrell as saying that the United States of America was not one of the countries which could be considered able to produce more food than it needed for its own requirements and therefore able to make up the deficiency of other countries. That seems a very startling idea. If one considers the area of the United States and its population of 150 millions in comparison with the density of population of the south European countries and that America could not produce a surplus of food, then the case of the south European countries seems absolutely hopeless. Did Dr. Sebrell really mean that under the present conditions of organization and nutrition, America is not a surplus food producer, but after re-organization might prove sometime to be a surplus food producer? Might it not produce more useful commodities, more food crops, on lands now used for producing tobacco and cotton?

Dr. W. Tomaszewski (21 Warrender Terrace Park, Edinburgh): In my country of Poland, although 65 to 70 per cent. of the people are agricultural, it is among the rural population that most of the underfeeding occurred. The towns are too small to absorb the big families which are the rule and their greatest problem is to transfer the rural population to the urban districts and to develop industry, which is the only way to deal with the difficulty. There has been emigration but that had stopped before the war.

Is it economically possible to solve the problem of nutrition so as to give the whole world population proper feeding?

Dr. J. A. B. Smith (Hannah Dairy Research Institute, Kirkhill, Ayr): With reference to the so called "backward" countries, is it not possible that some of these are not so backward as we are inclined to think. A considerable mass of scientific work has been done in China, for instance, and there would be a danger of international misunderstanding if we took too much on ourselves in the way of teaching these people.

Miss P. Wingfield (College of Domestic Science, 5 Atholl Crescent, Edinburgh): It is certainly a fact that there is too little contact between the experts in different fields but I look forward with great hope to the contact Mr. McDougall's permanent organization will be making with the universities, training centres and so forth. In many training centres themselves there is far too little contact between agriculture and domestic science and I am sure that these delegations will have the effect of bringing about more intercourse between the bodies contacted.

vor. 2, 1944] 
Professor H. Dryerre (Royal (Dick) Veterinary College, Edinburgh): I wish to stress a point raised by Sir John Orr and supported by Mr. $\mathrm{McD}$ ougall. Sir John referred to the fact that governments have undertaken to see that the recommendations of the Hot Springs Conference are brought into being, but no government will act enthusiastically in a matter of that nature unless it has the support of the community, and Sir John has urged the people to make the position quite clear that they want the implications of the Hot Springs Conference fully practised in this country. I suggest that all present should take every opportunity of talking about this matter with their friends and supporting any organization or meeting to which they have access, in order to voice their views and keep them firmly before the government to act as a driving force. I would mention the steps being taken by one scientific association. In Scotland next year, with the co-operation of the British Medical Association and The Nutrition Society and other interested parties, a national conference is going to be held on the whole question of the relationship of agriculture and nutrition to post-war needs. I suggest that all who are interested in this matter should make it their business to attend the conference, and I think it would be politically sound to try as far as possible to enlist the support of the press in this national, in fact international, effort for the betterment of the human race.

Dr. K. Evang gave the following replies:

To Dr. Smith: There is no doubt "backward" is not the right word to describe certain countries; perhaps "less advanced" is better. I would like to guard against one possible misconception. Under no circumstances will the permanent organization attempt to send a team to any country that does not ask for assistance. After discussing this point with representatives of some of these countries, my impression is that they are all extremely anxious to obtain help.

To Dr. Owen: One has to distinguish between the actual production of food at the present moment and the potential production. Dr. Sebrell's statement referred only to the production of food at the present moment. If the whole population of the U.S.A. were to be fed properly, they would have no surplus; on the contrary, they would have to depend on imports to a certain extent. I do not say that the U.S.A. would not, with proper organization of food production, be able in future to provide a surplus. There is also the British Commonwealth with all its different types of reserves, and in countries like Denmark, Sweden and Norway there are also enormous possibilities.

Mr.F.L.McDougall added to this reply: It is most important that nonAmericans should realize one particular feature of the American situation in regard to food. In the years 1930 to 1940, all the American people who studied nutrition were convinced that the mass malnutrition found in the area south of the Mason-Dixon line was as serious as any that existed in the depressed areas of this country. Since the U.S.A. has become the "Arsenal of Democracy" and has joined in the war, it has mobilized all its labour reserves to the maximum extent and so has got a condition of full employment. Under these circumstances, the food consumed in the areas which before were undernourished has gone up very markedly indeed. 
To come to the question of the future, no administration, whether Republican or Democratic, would be able to avoid taking steps to try to maintain full employment in the U.S.A. If that was the case, it could be assumed that the food consumption would be permanently at a higher level than before the war. Given intensification of agricultural production, the U.S.A. might once more become an exporter of surplus food. On the basis of pre-war practice, Dr. Sebrell was entirely correct. In the coming relief period, the fact that there has been a very great mass of serious malnutrition in the U.S.A., which has been largely rectified as the result of changed economic circumstances, is one that we ought to remember, because otherwise it might be a little difficult to understand why the supplies we should like to see forthcoming do not come forward in quite such large quantities as we might have hoped.

To Miss Wingfield: The Hot Springs Conference stressed the need for each nation to establish a national nutrition organization. The League of Nations has also urged that each government should establish a national nutrition organization, and about 25 countries accepted that recommendation before the war, and their representatives met at Geneva in 1938. These nutrition committees varied in composition. They included representatives from the following groups: nutritionists in the scientific sense, biochemists, men dealing with problems of practical nutrition, and scientific workers dealing with metnods of food preparation; there were also representatives of agriculture and economics, and from the producers' and consumers' organizations. Some of the committees were, therefore, large; the Norwegian one, for example, had about 30 members. The idea is that the coming permanent organization will suggest certain general rules for the establishment of such committees, and it is obvious that the institutions represented by Miss Wingfield and her domestic science colleagues will have to be taken into account.

\section{Mr. F. L. McDougall gave the following replies:}

To Dr. Mead: The Interim Commission is very fully aware of the importance of this anthropological approach to the nutrition problem. Every nation has its representative on the Commission and most of the members are diplomats. It would be a very useful thing if The Nutrition Society in this country would consider whether it had any suggestions to make in order to ensure that full consideration be given to the problem of how to organize the services. This point of Dr. Mead's was not particularly considered at the informal meeting held in July at Washington, but I am in favour of the idea of bringing special aspects of the problem before the Commission.

To Dr. Leitch: I am not much in sympathy with the idea that the permanent commission be asked to deal with magico-religious difficulties. There ought to be a cultural commission to deal with such questions.

With regard to the second question, the Hot Springs Conference has not attempted to reach any decision on that. An estimate of the total calorie requirements of Europe has been made in respect of the short term period. When figures such as "double the normal" calorie output are talked about, one has to assume a very large increase in animal food. voL. 2, 1944] 
If, for example, the diets of China or India were to be raised to the level of New Zealand, would the world be in any conceivable position to produce enough calories to feed the livestock?

In regard to a possible date for the permanent commission to come into being, I can only give my own opinion. The Interim Commission will no doubt do its utmost to have its recommendations in the hands of the different governments before the end of the year. Presumably the governments will have some comments to make upon them and probably 2 or 3 months will elapse during which governments will instruct their representatives as to what omissions or changes they desire in the scheme. It is possible the governments might give their general blessing to the scheme by April 1944. Then the question will arise: Will there be a sufficient number of governments that feel themselves free under the circumstances of war to commit their people to a permanent organization? All the British Commonwealth nations, the U.S.A. and the Latin American countries would have no difficulty, but some of the others might feel that, until they are in a position to consult their own people, they are not willing to make a long term commitment. Should that prove to be the case it is possible that steps would be taken to set up a nucleus of the permanent organization to function under the Interim Commission until such time as it is possible to set up a proper, fully responsible organization.

To Miss Andross: The sort of team that has been envisaged would be drawn from the staff of the permanent organization, people with administrative experience, nutritionists, persons with knowledge of agriculture and economics, men with special knowledge of animal hygiene, some with particular knowledge of crops. Home economics and the whole question of the preparation of food must be included, and I hope we will turn to some of the countries with some knowledge of how to cook food for our special experts in this line.

To Dr. Tomaszewski: In regard to the possibility of obtaining for every country a diet adequate for health, that must be regarded, first of all, as a national problem for each country. Every country has got to make its own best contribution to the solution of its own food problem, either directly or by trading. Help will be given as needed. It is not possible to envisage for a period of 10 or even 20 years a position in which the whole world will be able to obtain a diet equal to that recommended by the United States National Research Council. It should be economically possible, however, on the basis of the wisest possible utilization of foodstuffs, to meet basic nutritional requirements and that would have the effect of producing an astonishing improvement in national health in all the countries of the world. 